\title{
ANALISIS PERMAINAN TRADISIONAL DALAM IMPLEMENTASI PENDIDIKAN KARAKTER DI SEKOLAH DASAR
}

\author{
Muhammad Ragil Kurniawan
}

Pendidikan Guru Sekolah Dasar, Universitas Ahmad Dahlan, Yogyakarta

\section{Kata Kunci :}

Permainan tradisional

Sumber belajar

Pendidikan karakter

Sekolah dasar
Email penulis:

ragil.kurniawan@pgsd.uad.ac.id

\begin{abstract}
This study aims to examine how the linkage between traditional games in D. I Yogyakarta with subjects taught in elementary schools. This research is an analytical descriptive research with qualitative approach. The object of this research is the children traditional game (dolanan anak) in Yogyakarta and five subjects taught in elementary school. The method used is literature study supported by interviews from experts and practitioners of Yogyakarta culture. Data analysis used is qualitative data analysis. There are traditional games that can be used in six main subjects in Primary School. So, can be interpreted that the traditional game in Yogyakarta can be used as a source of learning to be attributed with subjects in Primary School. This is because the number of traditional games is relatively large therefore can accommodate all subjects.
\end{abstract}

\section{PENDAHULUAN}

Indonesia dikenal dengan negara dengan kekayaan aset budaya. Data dari Arifin dkk, (2014) menyebutkan Indonesia memiliki minimal 633 etnis bangsa. Data Kementrian Pendidikan dan Kebudayaan tahun 2016 menyebutkan jumlah adat istiadat masyarakat, ritus dan perayaan yang ada di Indonesia mencapai 1.368 jenis. Seni pertunjukan mencapai 1.209 jenis. Kemahiran dan kerajinan tradisional mencapai 1.656 jenis. Sedangkan tradisi dan ekspresi lisan mencapai 1.337 jenis. Tidak heran jika Indonesia menjadi ladang yang sangat 
subut dalam aspek penelitian kebudayaan. Kekayaan yang tak terbeli ini sudah selayaknya untuk disadari keberadaannya serta dijaga eksistensinya.

Disisi lain, nilai budaya menjadi tiang penyangga pembentukan bangsa yang berkarakter. Integrasi pengenalan budaya dan penanaman pendidikan karakter menjadi kombinasi yang ideal. Akar budaya yang menjadi penciri kepribadian suatu masyarakat sejatinya dapat dijadikan sebagai sarana penanaman pendidikan karakter pada peserta didik. Wagiran (2012) menyampaikan bahwa pengembangan karakter suatu bangsa tidak dapat dilepaskan dari aspek budaya yang selaras dengan karakteristik masyarakat bangsa itu sendiri, terlebih budaya yang bersumber dari kearifan lokal.

Menggali nilai-nilai budaya berbasis kearifan lokal merupakan upaya strategis dalam membangun karakter bangsa di era global. Sudah terbukti bahwa negara yang berhasil bertahan dan sukses di era globalisasi ini merupakan negara yang kuat menjaga nilai kearifan lokal didaerah masing-masing. Oleh karenanya layak untuk menggali karakter dan potensi permainan tradisional dalam rangka menjaga nilai kearifan lokal bangsa. Karena Permainan tradisional merupakan hasil penggalian dari budaya kita sendiri (Purwaningsih, 2006: 43)

Terdapat nilai-nilai pembentuk karakter positif dalam permainan tradisional. Sujarno (2011:119-121) menjabarkan bahwa dalam permainan tradisional terkandung lima nilai yang dapat membentuk karakter positif anak. Kelima nilai tersebut adalah: nilai pendidikan, nilai sportivitas, nilai gotong royong, nilai demokrasi, nilai moral, dan nilai keberanian. Dengan demikian Implementasi permainan tradisional oleh anak-anak dapat mempercepat internalisasi nilai-nilai positif tersebut pada jiwa anak. Dibutuhkan cara yang strategis untuk dapat mengimplementaskan permainan tradisional yang sudah tidak lagi populis di kalangan anak-anak.

Sekolah menjadi institusi yang strategis untuk dapat mengimplementasikan penanaman karakter positif pada anak dengan menggunakan sarana permainan tradisional. Implementasi permainan tradisional di sekolah tidak hanya bermakna sebagi sarana penanaman pendidikan karakter pada anak, namun juga sebagai sarana menjaga melestarikan warisan budaya bangsa. Sebagaimana disampaikan oleh Ni Putu Parmini (2015: 442) bahwa selain sebagai penerusan nilai dan spirit kearifan lokal, pemanfaatan permainan tradisional untuk pendidikan karakter juga untuk melestarikan eksistensi permainan tradisional itu sendiri.

Penelitian ini bertujuan untuk menganalisis nilai kearifan lokal dalam permainan tradisional Yogyakarta, dan juga mengkaji bagaimana keterkitan antara permainan tradisional di D. I Yogyakarta dengan mata pelajaran yang diajarkan di sekolah Dasar. Kajian tentang permainan tradisional ini menjadi penting saat siswa mulai digandrungi dengan permainan yang berbasis androit yang berujung pada berkurangnya aktifitas fisik dan aktifitas sosial siswa. Sebagaimana diutarakan Sujarno (2011:118) bahwa permainan era digital lebih bersifat individu dan kurang mengasah aspek sosial anak. Padahal aktifitas sosial menjadi bekal utama siswa dalam menghadapi kehidupan bermasyarakat.

Pendidikan karakter pada anak usia sekolah dasar bisa dilakukan melalui permainan tradisional yang dikenalkan dan dilaksanakan tidak hanya sekali dua kali tetapi diusahakan secara rutin. Dengan rutinitas tersebut nilai-nilai yang membentuk karakter anak dapat merasuk dalam jiwa anak (Sujarno, 2011: 122). Dengan demikian dapat dikatakan bahwa akaan lebih efektif jika pemanfaatan permainan tradisional sebgai sarana internalisasi pendidikan karakter dilakukan secara rutin di sekolah.

Implementasi permainan tradisional di sekolah mengalami kendala jika belum ditemukan analisis tentang keterkaitan permainan tradisional dengan materi pelajaran atau mata pelajaran yang ada di sekolah. Untuk mempermudah implementasi tersebut, dibutuhkan 
pemetaan yang mendalam tentang potensi permainan tradisional untuk diimplementasikan di sekolah. Implementasi dapat dilakukan dengan dua cara, implementasi pada pembelajaran dan implementasi di luar jam pembelajaran. Olehkarenanya penelitian ini mencoba menggali potensi permainan tradisional untuk dapat diimplementasikan didalam proses pembelajaran. Adanya pemetaan keterkaitan antara permainan tradisional materi yang ada mata pelajaran diharapkan dapat memudahkan guru dalam mendesain pembelajaran berbasis permainan tradisional sebagai sarana penanaman karakter positif bagi anak SD.

\section{METODE PENELITIAN}

Penelitian ini dilakukan menggunakan jenis deskriptif analitik, yang berakar pada latar ilmiah sebagai keutuhan dan mengandalkan manusia sebagai alat peneliti. Pada penelitian ini peneliti menyajikan hasil analisis penelitian secara deskriptif kualitatif. Situs dalam penelitian ini adalah permainan tradisional yang berbasis di Daerah Istimewa Yogyakarta. Sedangkan konteks pembelajaran yang digunakan hanya pembelajaran pada tingkat Sekolah Dasar (SD). Sumber data yang penulis gunakan untuk memperoleh data yang valid dan relevan dalam penelitian ini bersumber dari buku, jurnal ilmiah, situs pemerintah daerah Yogyakarta, arsip kebudayaan, hasil penelitian yang relevan, surat kabar, serta dokumen pribadi dan dokumen resmi lain yang berhubungan dengan permainan tradisional (dolanan anak) di Daerah Istimewa Yogyakarta. Adapun data wawancara diperoleh dari ahli pembelajaran serta pemerhati kebudayaan Daerah Istimewa Yogyakarta. Data wawancara dilakukan untuk mendukung serta menguatkan data yang diperoleh dari hasil penelusuran data tertulis.

Analisis data pada penelitian ini menggunakan jenis analisis kualitatif. Setiap catatan harian yang dihasilkan dalam pengumpulan data yang berasal dari analisis dokumen, observasi serta hasil wawancara diseleksi dan dirangkum menjadi sebuah narasi deskripsi. Data yang telah terkumpul bila di anggap masih kurang atau belum lengkap, dicari lagi pada sumbersumber yang relevan. Muara dari seluruh kegiatan analisis data kualitatif terletak pada pelukisan atau penuturan tentang apa yang berhasil diteliti.

\section{HASIL DAN PEMBAHASAN}

Proses pengklasifikasian permainan tradisional di DIY berdasarkan mata pelajaran ini dilakukan berdasarkan keketerkaitan sebuah konten atau aktifitas dalam permainan tradisional dengan beberapa mata pelajaran yang diajarkan di sekolah dasar. Keketerkaitan tersebut bisa berasal dari beberapa faktor, diantaranya: a) materi dalam sebuah mata pelajaran yang bisa ditemui dalam sebuah permainan tradisional tersebut. b) karakter yang terkandung didalam sebuah permainan tradisional yang sama dengan karakter nilai yang diajrkan pada sebuah mata pelajaran, hingga c) faktor covering atau peluang ketersambungan atau kemudahan sebuah permainan tradisional untuk dapat digunakan sebagai sarana/metode dalam menyampaikan materi mapel tertentu. Adapun acuan ruang lingkup materi yang digunakan untuk memetakan adalah berdasarkan ruang lingkup materi tiap matapelajaran yang ada dalam BSNP 2006, khususnya pada standar isi.

Adapaun hasil analisis keketerkaitan karakteristik maupun konten permainan tradisional dengan mata pelajaran dalam pendidikan sekolah dasar adalah sebagai berikut: Pertama, Keketerkaitan permainan tradisional dengan Mata Pelajaran Ilmu Pengetahuan Alam (IPA). Terdapat 12 permainan tradisional yang memiliki keterkaitan dengan pelajaran IPA. Keduabelas permainan tersebut adalah: Dingklik oglak-aglik, Dolanan Ancang-ancang Alis, Dolanan Benthik, Dolanan Gamparan, Dolanan Bekel, Dolanan Egrang, Gasing, Layanglayang, Paseran, Thuprok-Thuprok, Watu gatheng, dan Dolanan Kelereng. 
Keduabelas permainan tradisional yang memiliki keketerkaitan dengan matapelajaran IPA ini dilihat dari beberapa aspek. Beberapa diantaranya masuk dalam klasifikasi keketerkaitan dengan mapel IPA karena terdapat unsur materi yang terkandung mapel IPA atau keketerkaitan dari unsur alat permainan yang digunakan dalam permainan tersebut. Menurut Badan Standar Nasional Pendidikan 2006, ruang lingkup matapelajaran IPA pada satuan pendidikan sekolah dasar meliputi aspek: mahluk hidup dan proses kehidupan, Benda/materi, sifat-sifat dan kegunaannya meliputi, Bumi dan alam semesta, serta energi dan perubahanny. Keketerkaitan permainan tradisional pada mata pelajaran IPA lebih banyak pada konteks yang terahir, yaitu energi dan perubahannya yang meliputi: gaya, bunyi, panas, magnet, listrik, cahaya dan pesawat sederhana.

Keterkaitan antara permainan tradisional dengan matapelajaran IPA diantaranya dilihat dari unsur materi. Unsur materi tentang keseimbangan dapat ditemukan aktifitasnya pada permainan Dhingklik Oglak Aglik, Egrang dan Thuprok-thuprok. Materi tentang grafitasi dapat ditemukan aktifitasnya pada permainan Dhingklik Oglak Aglik, Egrang, ThuprokThuprok, Benthik, Bekel, gasing, dan Paseran. Materi tentang lingkungan hayati sekitar peserta didik dapat ditemukan dalam aktifitas pada permainan ancang-ancang alis. Unsur materi tentang kecepatan terdapat pada aktifitas permainan Benthik, Gasing, Dan Paseran. Unsur materi tentang rotasi terdapat pada aktifitas permainan gasing. Permainan LayangLayang mengandung unsur pengenalan arah angin. Unsur materi tentang daya terdapat pada aktifitas permainan watu gatheng, paseran, layang-layang, dan kelereng. Sedangkan materi tentang Ketepatan sasaran terdapat pada unsur permainan Watu Gatheng dan Kelereng. Selain melihat keterkaitan unsur permainan tradisional yang merupakan bagian materi dari pelajaran IPA, keterkaitan antara mata pelajaran IPA dengan permainan tradisional dapat dilihat dari unsur, alat atau bahan yang digunakan dalam permainan tradisional.

Tabel 1. Keberadaan materi dalam Pelajaran IPA pada permainan tradisional

\begin{tabular}{|l|l|l|}
\hline No & Materi dalam Pelajaran IPA & Terdapat pada Permainan \\
\hline 1. & Keseimbangan & Dhingklik Oglak Aglik, Egrang dan Thuprok-Thuprok \\
\hline 2. & Grafitasi & $\begin{array}{l}\text { Dhingklik Oglak Aglik, Egrang, Thuprok-Thuprok, } \\
\text { Benthik, Bekel, Gasing, dan Paseran }\end{array}$ \\
\hline 3. & Lingkungan hayati sekitar peserta didik & Ancang-Ancang Alis \\
\hline 4. & Kecepatan & Benthik, gasing, paseran \\
\hline 5. & Rotasi & Gasing \\
\hline 6. & Pengenalan arah angin & Layang-Layang \\
\hline 7. & Daya & Watu Gatheng, Paseran, Layang-Layang, Kelereng \\
\hline 8. & Ketepatan sasaran & Gatheng dan Kelereng \\
\hline
\end{tabular}

Kedua, Keketerkaitan permainan tradisional dengan mata pelajaran ilmu pengetahuan sosial (IPS). Terdapat 8 permainan tradisional yang memiliki keterkaitan dengan pelajaran IPS. Kedelapan permainan tradisional tersebut adalah: Dolanan soyang, Dolanan dayoh-dayohan, Ancang-ancang Alis, Lepetan, Paseran, Thuprok-thuprok, Dhelikan dan Engklek.

Sebagaimana mata pelajaran IPA, ketujuh permainan tradisional yang memiliki keketerkaitan dengan mata pelajaran (mapel) IPS ini dilihat dari beberapa aspek. Beberapa diantaranya masuk dalam klasifikasi keketerkaitan dengan mapel IPS karena terdapat unsur materi yang terkandung mapel IPS atau keketerkaitan dari unsur alat permainan yang digunakan dalam permainan tersebut. Menurut Badan Standar Nasional Pendidikan 2006, ruang lingkup matapelajaran IPS pada satuan pendidikan sekolah dasar meliputi aspek: a) Manusia, Tempat, dan Lingkungan, b) Waktu, Keberlanjutan, dan Perubahan, c) Sistem Sosial dan Budaya, dan d) Perilaku Ekonomi dan Kesejahteraan. Berdasarkan keempat jenis materi tersebutlah dilakukan analisis keterkaitan dengan permainan tradisional. 
Keterkaitan antara permainan tradisional dengan mata pelajaran IPS diantaranya dilihat dari unsur materi. Masing-masing permainan terdapat unsur materi IPS yang berbeda-beda. Pada permainan soyang terdapat unsur pengenalan kehidupan sosial sekaligus pengenalan tata pemerintahan desa. Pada permainan Dayoh-Dayohan terdapat unsur aspek utama dalam lingkungan keluarga dan sosial. Pada permainan Ancang-Ancang Alis terdapat unsur aspek utama dalm lingkungan alam sekitar serta saling ketergantungan antar individu, masyarakat dan lingkungan sekitar. Pada permainan Lepetan terdapat unsur materi tentang aspek utama dalam lingkungan sosial dan alam sekitar. Pada permainan Paseran terdapat pesan kebudayaan khususnya tentang aspek teknologi pada sebuah budaya tertentu. Sedangkan pada permainan Dhelikan dapat dikorelasikan pada beberapa kisah perjuangan khususnya pada konteks gerilya.

Jika pada permainan lain unsur utama terdapat pada konten permainannya, pada permainan Thuprok-Tuprok ini salah satu keketerkaitan dengan mapel IPS terdapat pada unsur peralatan yang digunakan. Peralatan yang digunakan pada permainan Thuprok-Thuprok mengandung unsur kebermanfaatan secara sosial ekonomi dari komponen kelapa. Sedangkan pada permainan Engklek siswa diajarkan untuk menghargai hak dan kewajiban sebagai individu dalam sistem sosial.

Selain beberapa unsur yang terkandung pada masing-masing permainan tersebut, pada umumnya ketujuh permainan diatas mengandung beberapa unsur lain yang melekat dengan materi pelajaran IPS di sekolah dasar. Beberapa ketrampilan lain yang terkandung pada mate pelajaran IPS dan dapat direalisasikan pada tujuh permainan tradisional diatas diantaranya adalah: ikut dalam kegiatan kelompok, menganalisis dan memecahkan masalah hingga menggunakan konsep ruang dan waktu.

Ketiga, Keketerkaitan permainan tradisional dengan Mata Pelajaran Matematika. Secara keseluruhan terdapat 15 permainan tradisional yang memiliki keterkaitan dengan pelajaran matematika. Kelimabelas permainan tradisional tersebut adalah: Ancang-Ancang Alis, Cublak-Cublak Suweng, Benthik, Dhakon, Gamparan, Gobak Sodor, Bekel, Egrang, Gasing, Layang-layang, Dham-Dhaman, Engklek, Lompat Tali dan Dolanan Kelereng.

Sebagaimana mata pelajaran sebelumnya, kelimabelas permainan tradisional yang memiliki keketerkaitan dengan pelajaran matematika ini dilihat dari beberapa aspek. Beberapa diantaranya masuk dalam klasifikasi keketerkaitan dengan mapel matematika karena terdapat unsur materi yang terkandung mapel matematika atau keketerkaitan dari unsur alat permainan yang digunakan dalam permainan tersebut.

Menurut Depdiknas 2006, matapelajaran matematika pada satuan pendidikan sekolah dasar meliputi aspek: 1) bilangan, 2) geometri, 3) pengolahan data. Cakupan bilangan antara lain bilangan angka, perhitungan, dan perkiraan. Cakupan geometri antara lain bangun dua dimensi, tiga dimensi, transformasi dan simetri, lokasi dan susunan berkaitan dengan koordinat. Cakupan pengukuran berkaitan dengan perbandingan kualitas suatu obyek, penggunaan satuan ukur dan pengukuran. Cakupan yang ditentukan Depdiknas tersebutlah yang digunakan peneliti untuk menganaisis keterhubungan permainan tradisional dengan matapelajaran matematika pada satuan pendidikan sekolah dasar.

Menggunakan cakupan dari Depdiknas 2006 diatas, terdapat minimal lima belas permainan tradisional yang memiliki keketerkaitan dengan matapelajaran matematika. Hasil analisis menunjukkan bahwa Ancang-ancang alis, cublak-cublak suweng, dhakon, bhekel, dan lompat tali mengandung unsur bilangan. Sedangkan pada permainan gobak sodor, engklek, layang-layang dan kelereng terdapat unsur geometri. Dolanan kelereng, lompat tali, benthik, gamparan, egrang, dan gasing mengandung unsur materi tentang pengolahan data. Beberpa diantara permainan tradisional diatas memiliki tidak hanya satu cakupan materi namun juga 
terdapat gabungan dari dua aspek (dari tiga aspek materimatematika) sekaligus. Diantaranya yeng memiliki banyak kandungan unsur materi adalah: lompat tali selain terdapat unsur bilangan juga terkandung unsur pengolahan data. Begitu juga dengan engklek, selain terdapat unsur bilangan namun juga memiliki unsur materi geometri.

Keempat, Keketerkaitan permainan tradisional dengan Mata Pelajaran Pendidikan Kewarganegaraan (PKn). Hasil analisis menyebutkan terdapat tujuh permainan tradisional yang memiliki keterkaitan dengan pelajaran PKn. Ketujuh permainan tradisional tersebut adalah: Dholanan Soyang, Dolanan Dayoh-dayohan, Dhingklik oglak aglik, Dhakon, Betengan, Gobak sodor, dan Engklek.

Menurut Badan Standar Nasional Pendidikan 2006 menyebutkan bahwa ruang lingkup mata pelajaran Pendidikan Kewarganegaraan tingkat satuan Sekolah Dasar meliputi aspek-aspek sebagai berikut: a) Persatuan dan Kesatuan bangsa, b) Norma, hukum dan peraturan, c) Hak asasi manusia, d) Kebutuhan warga negara, e) Konstitusi Negara, f) Kekuasan dan Politik, g) Pancasila, dan h) Globalisasi. Dari kedelapan ruang lingkup tersebut memiliki cakupan materi yang spesifik. Namun peneliti mencoba menggunakan cakupan umum materi PKn SD sebagai tolok ukur keketerkaitan konten permainan tradisional dengan pelajaran PKn.

Menggunakan cakupan atau ruang lingkup materi dari BSNP 2006 tersebut, terdapat minimal tujuh permainan tadisional yang memiliki keketerkaitan dengan matapelajaran PKn. Hasil analisis emnunjukkan bahwa permainan dolanan soyang mengandung unsur kekuasaan dan politik, dalam hal ini politik tingkat desa. Permainan Dayoh-Dayohan mengandung unsur materi tentang kebutuhan warga negara. Permainan Dhingklik Oglak Aglik mengandung unsur kebutuhan warga negara dan sekaligus tentang persatuan dan kesatuan bangsa. Permainan Dhakon secara prinsip mengandung unsur materi tentang kebutuhan warga negara untuk bergotong royon. Betengan serta Gobak sodor memiliki prinsip yang mengandung unsur persatuan dan kesatuan bangsa, konstitusi negara serta Globalisasi. Sedangkan pada permainan Engklek terkandung unsur norma, hukum dan peraturan.

Kelima, keketerkaitan permainan tradisional dengan Mata Pelajaran Bahasa Indonesia. Diantara beberapa permainan tradisional yang memiliki keterkaitan dengan dengan pelajaran Bahasa Indonesia adalah: Dholanan Soyang, Dholanan Dayoh-dayohan, Ancang-ancang alis, Cublak-cublak suweng dan Lepetan. Lima permainan tradisional tersebut yang terindikasi memiliki keterkaitan dengan pelajaran matematika.

Ruang lingkup materi pembelajaran Bahasa Indonesia untuk sekolah dasar relatif lebih spesifik, jelas namun menyeluruh. Menurut Badan Standar Nasional Pendidikan 2006 menyebutkan bahwa ruang lingkup mata pelajaran Bahasa Indonesia tingkat sekolah dasat ada empat, antara lain: mendengarkan, berbicara, membaca, dan menulis. Kelima permainan tradisional yang masuk dalam kategori dekat dengan mata pelajaran Bahasa Indonesia sekolah dasar diatas semuanya mengandung unsur mendengarkan dan berbicara. Keseluruhan lima permainan tradisional yang dekat dengan pelajaran bahasa indonesia ini terdapat unsur bermain peran. Pada kegiatan bermain peran tersebutlah siswa secara tidak langsung menerapkan prinsip mendengarkan dan praktik berbicara.

Keenam, Keketerkaitan permainan tradisional dengan Mata Pelajaran Olah Raga. Diantara beberapa permainan tradisional yang memiliki keterkaitan dengan dengan pelajaran olah raga adalah: Linang Alihan, Betengan, Gobak sodor, Egrang, Thuprok-thuprok, Engklek, dan lompat tali. Tujuh permainan tersebut yang terindikasi memiliki keterkaitan dengan pelajaran olah raga $\mathrm{SD}$. 
Ruang lingkup materi pendidikan jasmani, olah raga dan kesehatan meliputi aktifitas permainan, olah raga fisik dan kesehatan. Sebagaimana yang ditentukan oleh Badan Standar Nasional Pendidikan 2006 bahwa terdapat tujuh cakupan dalam materi pelajaran PJOK sekolah dasar, antara lain: Permainan dan olahraga, Aktivitas pengembangan, Aktivitas senam, Aktivitas ritmik, Aktivitas air, Pendidikan luar kelas, dan Kesehatan. Mengacu pada tujuh ruang lingkup materi pelajaran PJOK SD tersebut maka permainan tradisional yang masuk kategori dekat dengan pelajaran PJOK ada tujuh permainan tradisional. Ketujuh permainan tradisional yang masuk kategori PJOK ini kesemuanya mengandung unsur aktifitas olah raga, ritmik, dan pendidikan luar kelas.

Karena jumlah permainan tradisional yang relatif banyak maka dapat mengakomodasi semuamata pelajaran. Semua mata pelajaran ada permainan tradisional yang mewakilinya. Dengan kata lain, fleksibilitas penggunaan permainan tradisional dalam konteks mata pelajaran sangatlah terbuka. Tidak sedikit juga permainan tradisional yang dapat digunakan untuk lintas mata pelajaran. Misalnya dalam penggunaan satu permainan tradisional terkandung materi/unsur 2 sampai dengan 3 mata peajaran sekaligus. Sehingga permainan tradisional juga memungkinkan untuk digunakan dalam konteks pembelajaran tematik dalam kurikulum 2013. Oleh karenanya peluang pemanfaatan permainan tradisional dalam kurikulum 2013 tetap terbuka luas.

\section{KESIMPULAN}

Semua mata pelajaran yang diajarkan di sekolah dasar terdapat permainan tradisional yang permainan tradisional yang mewakilinya. Secara implisit terdapat 12 permainan tradisional yang memiliki keterkaitan dengan pelajaran IPA. Terdapat 8 permainan tradisional yang memiliki keterkaitan dengan pelajaran IPS. Secara keseluruhan terdapat 15 permainan tradisional yang memiliki keterkaitan dengan pelajaran matematika. Terdapat tujuh permainan tradisional yang memiliki keterkaitan dengan pelajaran PKn. Terdapat lima permainan tradisional yang memiliki keterkaitan dengan pelajaran bahasa indonesia. Serta terdapat tujuh permainan tradisional yang secara implisit memiliki keterkaitan dengan pelajaran olah raga. Sehingga dapat dimaknai bahwa permainan tradisional di D. I Yogyakarta dapat digunakan sebagai sumber belajar untuk dikaitkan dengan matapelajaran di SD

\section{DAFTAR RUJUKAN}

Arifin, Evi Nurvidya., Ananta, Aris., Utami, D. R. W. W. Uncovering indonesia's ethnic diversity: the national, provincial, and district level. Presented at an ISEAS's public seminar. Singapore 18 November 2014.

Kementrian Pendidikan dan Kebudayaan. 2016. Statistik kebudayaan 2016. Jakarta: Pusat Data dan Statistik Pendidikan dan Kebudayaan Kementerian Pendidikan dan Kebudayaan.

Partini, Ni Putu. 2015. Eksistensi cerita rakyat dalam pendidikan karakter siswa SD di Ubud. Jurnal Kajian Bali. Volume 05, Nomor 02 Oktober 2015: hal 441-460.

Purwaningsih, Ernawati. 2006. Permainan tradisional anak: salah satu khasanah budaya yang perlu dilestarikan. Jatra. Vol 1 Nomor 1, Juni 2016: hal 40-46.

Sujarno. 2011. Permainan tradisional sebagai jembatan pembentukan karakter bangsa. Jantra Vol. VI, No. 12, Desember 2011: Hal. 116-123.

Wagiran. 2012. Pengambangan karakter berbasis kearifan lokal hamemayu hayuning bawana. Jurnal Pendidikan Karakter. Tahun II, Nomor 3 Oktober 2012; Hal. 329-339. 